\title{
Wanda Decyk-Zięba, Leksykon geograficzny bazylianina Hilariona Karpińskiego. Studium historycznojęzykowe (wybrane zagadnienia), Wydawnictwo Uniwersytetu Warszawskiego, Warszawa 2009, ss. 326
}

Recenzowana książka wyrasta z głównego nurtu badawczego w dotychczasowym dorobku naukowym autorki (jakim są dzieje obcych, głównie wschodniosłowiańskich, nazw geograficznych w języku polskim), jednak w dwu wymiarach przekracza jego ramy. Po pierwsze, w centrum zainteresowań badawczych znalazła się całość obcego nazewnictwa geograficznego (a więc nie tylko zdecydowanie dotąd przeważające nazwy wschodniosłowiańskie), po drugie, głównym przedmiotem opisu, analizy i interpretacji jest jednostkowe dzieło - pierwszy polski słownik geograficzny, z wielu względów bardzo interesujący, a jednocześnie nieobecny w obiegu naukowym. Stąd, jak deklaruje autorka: „Podstawowym celem rozprawy jest prezentacja samego słownika i zgromadzonego w nim nazewnictwa" (s. 13). Uszczegółowieniem tej deklaracji jest passus: „Niniejsza rozprawa ma charakter historycznojęzykowy. Podstawę analizy stanowi tekst, który jest ujmowany w różnych płaszczyznach: w perspektywie leksykograficznej (słownik Karpińskiego a słowniki dwu- i wielojęzyczne i słowniki geograficzne), onomastycznej (w kontekście kształtowania się nazewnictwa obcego w polszczyźnie), historycznojęzykowej (ze szczególnym zwróceniem uwagi na właściwości północnokresowe języka druku) oraz kulturowej (jako dokument epoki i postawy jego autora - bazylianina - wobec świata). Przyjęcie takiej hierarchii zadań badawczych zadecydowało o celach, charakterze, zakresie i ostatecznym kształcie pracy" (s. 17). Cele te autorka scharakteryzowała następująco: „Cele szczegółowe pracy to:

- po pierwsze: ukazanie związków kulturalnych Polski z Zachodem w kontekście nazewnictwa geograficznego występującego w słowniku. [...]

- po drugie: pokazanie historii słowników geograficznych w kontekście zarówno poszukiwań pierwowzoru, jak i przewartościowań zachodzących 
w relacji łacina - języki nowożytne, które przekładają się też na relacje nazewnictwo łacińskie - nazewnictwo nowożytne. [...]

- po trzecie: znalezienie pierwowzoru; ponieważ dzieła wówczas wydane miały charakter kompilacyjny, przyjęto jako wstępne założenie badawcze hipotezę, że istniał jakiś słownik zachodnioeuropejski (najprawdopodobniej francuski), który stanowił podstawę leksykonu Karpińskiego. [...]

- po czwarte: pokazanie zarówno ogólnych zasad transpozycji nazewnictwa obcego do tekstu polskiego [...], jak i bardziej szczegółowych na przykładzie materiału onomastycznego z obszaru należącego do jednego państwa (w tym wypadku Rosji). [...]

- po piąte: analiza języka druku pod kątem jego reprezentatywności regionalnej $[\ldots]$

- po szóste: poszukiwanie odpowiedzi na pytanie: co nowego wniósł Karpiński jako bazylianin i mieszkaniec WXL do słownika, co zaakceptował, co podkreślił i co zmienił? [...]

Podział pracy na rozdziały wynika z postawionych celów szczegółowych" (s. 17-21).

Metodologię rozprawy narzucił jej przedmiot. Autorka posłużyła się filologiczną metodą opisu tekstu i instrumentarium badawczym onomastyki porównawczej. Dzięki tym adekwatnym do założeń rozprawy narzędziom badawczym osiagnęła planowany cel. Powstała praca obszerna, w zamierzonym zakresie wyczerpująca, wyjątkowo bogata w płaszczyźnie informacyjnej i nowatorska na gruncie historii języka polskiego w tym sensie, że przynosząca charakterystykę swoistego, dotąd nieopisywanego kompleksowo tekstu, jakim jest słownik geograficzny. O jej wartości stanowią - moim zdaniem - przede wszystkim następujące aspekty i elementy:

1. Wybór przedmiotu rozprawy. Jak już wspomniałem wyżej, leksykon Karpińskiego z przyczyn nie do końca jasnych nie funkcjonuje w obiegu naukowym. Współcześnie w zasadzie nieznany, później został niemal zupełnie zapomniany (diametralnie różne były losy drugiego z kolei dzieła tego typu Dykcjonarzyka geograficznego Franciszka Siarczyńskiego). Dopiero w ostatnich dziesięcioleciach pojawiają się lakoniczne o nim wzmianki, głównie w pracach historyków, w mniejszym stopniu - geografów zainteresowanych dziejami swojej dyscypliny. Ma zatem rację autorka, konstatując: „Było więc to dzieło po części niedocenione, po części zapomniane. Przypomnieć o tym słowniku, zwrócić uwagę na jego autora i formację zakonną, do której należał, wydawało się rzeczą potrzebną i słuszną" (s. 12).

2. Imponujące podstawy źródłowe i zaplecze erudycyjne rozprawy. Spis źródeł (s. 299-305) liczy 61 pozycji w dziale Słowniki językowe, onomastykony, encyklopedie, 30 pozycji (23 zachodnioeuropejskie i 7 polskich) w dziale 
Słowniki geograficzne, 8 pozycji w dziale Prasa i 57 - w dziale Inne źródła. Spis literatury przedmiotu (s. 306-316), w którym nie dostrzegam żadnych istotnych luk [oczywiście, zawsze można by to i owo dorzucić, na przykład do kwestii szkolnictwa jezuickiego wyzyskała autorka niewatpliwie wartościową, ale jednak już trochę przestarzałą książkę Stanisława Bednarskiego Upadek i odrodzenie szkół jezuickich w Polsce. Studium z dziejów kultury i szkolnictwa polskiego (Kraków 1933) i nową, lecz bardzo zwięzłą pracę Ludwika Piechnika Przemiany $w$ szkolnictwie jezuickim $w$ Polsce $w$ XVIII wieku (w: Z dziejów szkolnictwa jezuickiego w Polsce. Wybór artykułów, red. J. Paszenda, Kraków 1994, s. 183-209), zabrakło natomiast doskonałej książki Lecha Słowińskiego Nauka języka polskiego w szkołach Rzeczypospolitej przedrozbiorowej (Poznań 1978)], liczy 295 pozycji (43 pozycje to strony internetowe), z czego 128 to książki, nieraz bardzo obszerne, czasem wielotomowe. Należy przy tym podkreślić, że nie chodzi tu bynajmniej o erudycyjny popis: znajomość rozległej literatury przedmiotu ma charakter „sfunkcjonalizowany”, jej wyniki, umiejętnie uzyskane przez autorkę, są obecne i widoczne w tekście jej pracy, która dzięki temu zyskuje na głębi i gruntowności.

3. Samoistna wartość informacyjna licznych i obszernych często przypisów, które poza funkcją dokumentacyjną przynoszą wiele informacji luźniej związanych z głównym tokiem wywodu autorki, ale niezwykle cennych, nierzadko odkrywczych, a zawsze (zwłaszcza dla historyka języka, filologa i kulturoznawcy) bardzo interesujących.

4. Gruntowność, wielostronność i wnikliwość analizy i interpretacji. Dość powiedzieć, że w pierwszym rozdziale autorka wyczerpująco opisała nazwy własne w słownikach dwu- i wielojęzycznych z językiem polskim (od dykcjonarza Murmeliusza do Mownika Trotza) i w słownikach geograficznych (od dzieła Orteliusa z 1578 roku po Dykcjonarzyk Siarczyńskiego), w drugim, poszukując pierwowzoru leksykonu Karpińskiego, opisała pierwsze drukowane słowniki geograficzne łacińskie, a następnie słowniki francuskie i angielskie (ilustrując różnice między nimi porównawczymi zestawieniami wybranych artykułów hasłowych), polskie XVIII-wieczne podręczniki do geografii i na ich tle słownik Karpińskiego itd. (tzn. podobnie obszernie, precyzyjnie i wyczerpująco w pozostałych rozdziałach).

Warsztat naukowy Wandy Decyk-Zięby odznacza się dwiema szczególnie cennymi i pożądanymi cechami. Są to:

1. Solidne podstawy źródłowo-materiałowe formułowanych tez i wniosków.

2. Postawa badawcza, cechująca się sumiennością, skrupulatnością i filologiczną akrybią na każdym etapie postępowania badawczego, umiejętnością łączenia gruntownej, wielostronnej i szczegółowej analizy z dobrze uzasadnio- 
ną, podbudowaną obfitym materiałem syntezą, a także chwalebną ostrożnością w wyciaganiu wniosków i formułowaniu tez.

Dzięki takiemu warsztatowi badawczemu Wanda Decyk-Zięba osiagnnęła w recenzowanej książce wiele ważnych i wartościowych wyników naukowych, które weszły do trwałego dorobku językoznawstwa polskiego. Tytułem przykładu wskażę kilka z nich:

1. Przekonujące ustalenie, że pierwowzorem leksykonu Karpińskiego była francuska wersja (opracowana przez Jeana Baptiste'a Ladvocata) słownika geograficznego angielskiego historyka Lawrance'a Echarda (najwięcej cech wspólnych polski tekst wykazuje z przekładem włoskim z roku 1749 - Karpiński przebywał w Rzymie w latach 1743-1750, a także z edycją paryską z roku 1747 i amsterdamską z 1748).

2. Wielostronne uzasadnienie tezy, że ,Słownik [Karpińskiego - B.W.] wpisuje się w główny nurt zmian, jakie objęły obce nazewnictwo geograficzne [...] w polszczyźnie: zastępowania nazw zaadaptowanych (egzonimów) współczesnymi formami nieprzyswojonymi” (s. 287-288).

3. Wykazanie, że „Słownik [Karpińskiego - B.W.] był sumą wiedzy geograficznej o świecie: pokazywał świat w wielu jego wymiarach w sposób rzeczowy i zobiektywizowany. Autor słownika patrzył na świat oczyma i Europejczyka, i bazylianina, i mieszkańca Wielkiego Księstwa Litewskiego. Te różne perspektywy oglądu są widoczne i w warstwie treściowej, i w formie językowej tekstu” (s. 288); „Postawę autora pierwszego polskiego słownika geograficznego wobec świata cechują: europocentryzm, przywiązanie do wartości chrześcijańskich, otwartość na inne kultury i optymizm” (s. 287).

Jestem przekonany, że bardzo wartościowa i atrakcyjna pod względem czytelniczym książka Wandy Decyk-Zięby znajdzie wielu odbiorców. Oprócz historyków języka i onomastów można ją polecić historykom kultury, nauki i geografom zainteresowanym dziejami swojej dyscypliny. 